have come from there, and I can only imagine it must have been an upheaval from somewhere near the spot. I may mention the soundings on the chart show over 2000 fathoms. There was a subnarine volcano near the spot in 1789 ."

EXPERIMENTS on the liquefaction of oxygen and nitrogen are described by Wroblewski and Olszewski (Compt. Rend. xcvi. I 140 and r225). At $-136^{\circ}$ oxygen liquefies under a pressure of $22 \frac{1}{2}$ atmospheres; nitrogen at the same temperature does not liquefy, even under a pressure of 150 atmospheres, but if the pressure is somewhat slowly diminished, care being taken that it does not become less than 50 atmospheres, the nitrogen becomes liquid. Carbon disulphide solidifies at about $-116^{\circ}$, and alcohol at $-130^{\circ} \cdot 5$.

FROM the annual report on the mineral statistics of Victoria, we see that the quantity of gold raised in 1882 was 864,609 oz., as against $833,378 \mathrm{oz}$. in $\mathrm{r} 88 \mathrm{r}$. The deepest shaft in the colony is the Magdala, at Slawell, 2409 feet deep.

THE additions to the Zoological Society's Gardens during the past week include a White-fronted Capuchin (Cebus albifrons of) from Brazil, presented by Capt. Harrison; a Puma (Felis concolor) from South America, presented by Mr. B. M. Whithard; a Grey Ichneumon (Herpestes griseus) from India, presented by Mr. Murray Dickinson; a Ruddy Ichneumon (Herpestes smithi) from South Africa, presented by Col. J. H. Bowker, F.Z.S. ; a Fallow Deer (Cervus dama $\$$ ), European, presented by Sir Henry Bessemer; a Persian Gazelle (Gazella subgutterosa of), two Persian Sheep (Ovis aries, var. of of) from Persia, presented by Lady Brassey; a Grey Seal (Halicharus gryphus) from Wales, presented by Mr. J. J. Dodgshon; two Rufous Tinamous (Rhynchotus rufescens) from Uruguay, presented by Mr. J. Brown; a Spanish Terrapin (Clemmys leprosa), South European, presented by $\mathrm{Mr}$. Aitchison; a Yellow-billed Sheathbill (Chionis alba) from Antarctic America, two Yarrell's Curassows (Crax carunculata of $\varsubsetneqq$ ) from South-east Brazil, purchased; a Macaque Monkey (Macacus cynomolgus of) from India, a Greater Sulphur-crested Cockatoo (Cacatua galerita) from Australia, two Small Hill Mynabs (Gracula religiosa) from Southern India, reposited.

\section{THE IRON AND STEEL INSTITUTE}

THE Iron and Steel Institute has this year resolved to revisit the place of its birth-in other words, the young and flourishing town of Middlesbrough-on-Tees, where the association was founded some fifteen years ago. The arrangements for its reception and for visits to different works in the neighbourhood (though marred in practice by a grievous disaster) left nothing to be desired; but the papers, thouxh sufficient in number and value for practical metallurgists, offer very little that is of interest to the student of science generally. Hence our notice will be brief. It is sumewhat to be regretted (especially seeing that the Eston Works formed the first day's excursion) that no paper was devoted to the development of the Thomas-Gilchrist or "basic" process of steel-making. This process has been widely and successfully adopted in Germany, but has made little progress as yet in the Cleveland district, for which it may be said to have been specially designed, and where it was first put in practice. On this disappointment, however, it is useless to dwell. Passing over three adjourned discussions-on tin-plate making, coal-washing machinery, and the manufacture of anthracite pig iron respectively-we come to the new papers prepared for the meeting. There were two dealing with the important manufacture of coke: one by $\mathrm{Mr}$. $\mathrm{R}$. Dixon, on the Simon-Carve's process, and one by Mr. Jameson, on the process which bears his name. We hail these as a further assurance that the barbarous, costly, and offensive beehive oven, which still continues to disgrace our English coking districts, is far on the high road to extinction. In Belgium it has altogether ceased to exist, being superseded by more rational methods; and the same will soon be the case for the rest of the
Continent. The two papers before us do not, however, contribute very much to our knowledge. Mr. Dixon's deals simply with the cost of erecting ovens on the particular system described, which cost is unfortunately high, and on the yield and quantity of coke produced, which are both satisfactory. Some difficulty is experienced with the bituminous coal of Durham in keeping the valve-boxes and mains free from pitch; but this, it is hoped, will shortly be overcome. He also describes a method just intrcduced of heating the air required for combustion by the waste gases passing away from the ovens, by which the time needed for coking is expected to be largely reduced. Mr. Jameson's system, as our readers will remember, consists in burning the coal from the top in a closed oven, and withdrawing the gases, as they form, from the bottom, by means of an exhausting apparatus. These waste gases are condensed, and give valuable results in ammonia, tar, \&c. The amount of this yield has been largely increased, since former papers were read on the subject, by new extracting and condensing appliances, and the percentage of coke made appears also to have improved. One great advantage of the system is that any beehive oven can be adapted to it at a co t of some $\mathbf{1 0 l}$. or $15 l$. The oils extracted, the value of which had been questioned, find a ready sale at $2 l$. to $3 l$. per ton.

A paper on raw coal in the blast furnace, prepared by $\mathrm{Mr}$. I. Lowthian Bell, F.R.S., was postponed, in consequence of its author's serious illness-an illness from which we are glad to hear that he is recovering. We pass on to a paper by Mr. E. A. Cowper, Past President of the Institute of Mechanical Engineers, on the results obtained with the hot-blast stove which bears his name. This, as is well known, is an application to the blast furnace of the fire-brick "regenerator" invented by Sir Wm. Siemens for gas furnaces. In the earlier days of the hot-blast process, the best known means of heating the air wato pass it through a sort of coil of cast-iron pipes, inclosed with in a tall furnace. The limit of endurance with such pipes is, however, reached at about $1000^{\circ} \mathrm{F}$.; whereas by employing two inclosed stacks of fire-bricks, one of which is always being heated from below, while the other is being cooled from above by air passing through it to the furnace, temperatures of $1500^{\circ}$ are attainable. The advantages of so far increasing the temperature were hotly contested, from a theoretical point of view ; but "the proof of the pudding is in the eating," and $\mathrm{Mr}$. Cowper has proved beyond doubt that a blast of $1500^{\circ}$, combined with a very large and slowly-working furnace, will realise an econumy (in fuel consumed per ton of iron made) which, in these days of competition, means just the difference between a fair profit and a heavy loss. The chief element of success in these stoves appears to be the making of the bricks as thin as possible, so that there may be but little depth for the heat to soak into or soak out of; and the author describes a form of brick, making what he calls "honeycomb filling," with which there is nowhere a greater thickness than two inches, and this is always heated from both sides.

Two papers on hydraulic cranes for steel works, by Mr. R. M. Daelen and Mr. T. Wrightson, and another by Mr. J. E. Stead, on a new form of gas sampler, do not require any special comment. Finally we have a paper on blast furnace economy in relation to design, by Mr. R. Howson, which is of a somewhat more suggestive character. The almost nniversal form of the interior of a blast furnace is as follows :-From the throat, where the materials are charged and the gases collected, it widens slowly to a point about two-thirds of the way down, called the boshes. From thence it narrows again, but more rapidly, and ends in a shallow circular pit called the hearth. Mr. Howson asks whether this form has not, from beginning to end, been a "rule-of-thumb business" with English engineers ; and whether the rapid narrowing below the boshes does not in fact favour the lodgment of half-melted cinder, and the conse. quent building up of "scaffolds," which are known to be the most serious of all impediments to the successful working of a blast furnace. It is supposed that the hearth needs "relief from pressure;" but as a matter of fact the difficulty is to get the materials down quickly enough, and the easier their descent is made the better. He proposes a barrel-shaped form, having a regular curve at the boshes, instead of a sharp angle-a form actually adopted by the late Mr. Menelaus at Treforest, and with great success as to economy of fuel. With the same object he advocates the charging of the coke towards the sides of the furnace, and the stone towards the middle, and the preserving of this distribution throughout, so as to have as much combustible material as possible above and near to the tuyeres. 